\title{
Assessment of the Upstream Churia Hills and Downstream Terai Plains Linkage: An Environmental Services Perspective
}

\begin{abstract}
B.K. Singh ${ }^{1}$
The Terai, considered the granary of $\mathrm{Nepal}$, is facing serious threat from siltation originating from the Churia hills mainly due to heavy deforestation together with forest and watershed degradation. Discussions with local community people revealed that no such problem existed 5-6 decades ago when the Churia forest was intact. All the forestry sector policies had recognized the Churia hills as fragile and environmentally sensitive, but the concerned government agencies and the local community people have not been able to conserve this region effectively. There is heavy exploitation of the Churia hills for the extraction of timber, firewood, non-timber forest products, and for grazing resources. In addition, gravel, sand and boulders are also being extracted for the sake of revenue to the local governments. Jalad River of Dhanusha district originating from the Churia hills has been converting fertile and productive agriculture lands into barren river beds at the rate of 25 hectares a year. The Churia hills should be conserved for the environmental services of the watershed to the entire Terai region rather than for provisioning tangible forest products services only to the upstream local communities.
\end{abstract}

Key Words: Environmental services, Churia-Terai linkage, PES, upstream-downstream

$\mathbf{T}$ he National Conservation Strategy (1988) and other policies had recognized the Churia hills as a fragile and environmentally sensitive ecosystem that must be preserved. Similarly, the LRMP (1986) had classified the Churia hills as 'protection forest'. But the Churia hill forest resources and watershed conditions have been rapidly degraded due to its overexploitation for timber, firewood, non-timber forest products such as bamboo; over-grazing; and frequent forest fires in a classic case of 'the tragedy of commons' (Hardin, 1968). Due to their rapid degradation, the Churia hills have turned into a source of siltation. Consequently, valuable agricultural lands of the Terai, considered the 'granary for Nepal' have been rendered into unproductive river-beds. This study assesses how the over-exploited land use of the upstream Churia hills resources has negatively affected the downstream Terai people along the perspective of the environmental services linking the Churia Hills to the Terai Plains.

The Costa Rican Forest Law 7575, cited in Mayrand \& Paquin, 2004, provides a definition of environmental services as follows: "Those services provided by forests and forestry plantations that have an impact on environmental protection and improvements. They are: mitigation of greenhouse gas emissions (fixing, reduction, sequestration, warehousing and absorption); protection of water for urban, rural or hydroelectric use; biodiversity protection to conserve it and for sustainable, scientific and pharmaceutical use; genetic research and improvement; protection of ecosystems, life forms and natural scenic beauty for tourism and scientific ends".

Further, Wunder (2005) classified Payment for Environmental Services (PES) schemes into four services: (i) carbon sink functions: such as an electricity company paying farmers in the tropics for planting and maintaining additional trees, (ii) hydrological functions: downstream water users paying upstream farmers for adopting land uses that limit deforestation, soil erosion, flooding risks, (iii) biodiversity: conservation donors paying local people for setting aside or naturally restoring areas to create a biological corridor, and (iv) landscape aesthetics/ecotourism: tourism operators paying a local community not to hunt in a forest being used for tourists' wildlife viewing. Wunder had defined the principle of PES as a voluntary, conditional agreement between at least one "seller" and one "buyer" for well-defined environmental services - or a land use presumed to produce those services i.e. if the provider continuously secures the

\footnotetext{
${ }^{1}$ A free-lance forestry consultant working in Nepal. Email: singhbk@ntc.net.np
} 
provision of the service (conditionality). This concept suggests that PES schemes can enable both sellers and buyers of environmental services to be better off and at the same time help to better conserve the resource base.

With the need for ecosystem management to ensure a supply of ecosystem goods and services, a number of innovative financing mechanisms have been adopted in different countries because public budgets for this purpose have fallen short. PES is a kind of voluntary contractual arrangement that is implemented as a conservation financing mechanism to achieve the dual goal of environmental conservation and poverty reduction in developing countries.

For PES to work, the downstream benefits must be more than the opportunity costs of the land use changes upstream. How much the downstream beneficiaries should pay depends on the quantity of benefits they receive or damage they suffer as a result of change in upstream land uses while how much the upstream service providers should be willing to bear as compensation depends on opportunity costs to them.

Upstream land uses are the issues that are addressed and payments are made to bring changes in improved land use practices that can contribute to the watershed services. Out of the four environmental services, the discussion is focused on watershed services. Practices of PES financed by the users and/or government in other countries include: Ecuador (Wunder and Alban, 2007), PES in Costa Rica (Pagiola, 2007), the payments for hydrological environmental services (PSAH) program in Mexico (Muñoz et al., 2007), payments for watershed services in Pimampiro, Cauca Valley Watershed Management, Colombia (Wunder and Alban, 2007), and Sukhomajri, India.

Pagiola (2007) reported that Costa Rica had pioneered the use of payments for environmental services (PES) in developing countries by establishing a formal, country-wide program of payments (Pago por Servios Ambientales, PSA). The PSA has been partly credited for helping the country, once known for having one of the world's highest deforestation rates, to achieve negative net deforestation by the early 2000s. In the beginning of 1997, Costa Rica developed an elaborate PES program. The Forest Law No. 7575, enacted in 1996, explicitly recognized four environmental services provided by forest ecosystems: (i) mitigation of greenhouse gas emissions; (ii) hydrological services, including provision of water for human consumption, irrigation, and energy consumption; (iii) biodiversity conservation; and (iv) provision of scenic beauty for recreation and ecotourism.

\section{Materials and methods}

This research was carried out in the upstream and downstream VDCs of the Jalad River in Dhanusha district, Nepal (Figure 1). Three sub-watersheds regions of the Jalad river namely: Jagadhar, Chamainiya and Jalad streams itself were selected. Jagadhar stream flows in the eastern part and Jalad stream in the western part whereas Chamainiya in the middle part of the watershed area. These three streams meet at the Churia foothills and flow down to Bhabar and Terai region as the Jalad River. The total length of the Jalad River is $55 \mathrm{~km}$ from its origin to the Indian border. The Jalad River, originating from the Churia hills, is a seasonal river. The study was conducted during 2006-2008. Of the total 1635 riveraffected households, 627 households $(\sim 38 \%)$ in 10 VDCs were surveyed and interviewed to assess the effects of the river. Sample design was based on simple random sampling method.

Analysis of household data was also done on upstream, midstream and downstream VDCs. In the upstream, there were two VDCs namely Pushpalpur and Hariharpur. The upstream VDCs had forest resources and the households were within $5 \mathrm{~km}$ distance and had easy access to the Churia forest resources such as fodder, grazing, firewood, timber and non-timber forest products. Some also had access to and control over community forests. Four VDCs namely Digamberpur, Sakhuwa Mahendranagar, Tarapatti Sirsiya and Gopalpur were part of the midstream, within 5-10 km distance from the Churia foothill. The midstream households had limited or no access to government forest resources of the Churia hills such as firewood, timber and some nontimber forest products. The downstream (beyond 10 $\mathrm{km}$ distance from the Churia foothills) covered four VDCs of Baniniya, Bainga Shivpur, Kachuri Thera and Andupatti Katharait. The households of the downstream VDCs did not enter the forests of the Churia hills for any forest products. They did not have access to any kind of forest products. But one commonality shared by all the households from the upstream, midstream and downstream was the negative effects of the Jalad River: either by riverbank cutting and/or by siltation. 


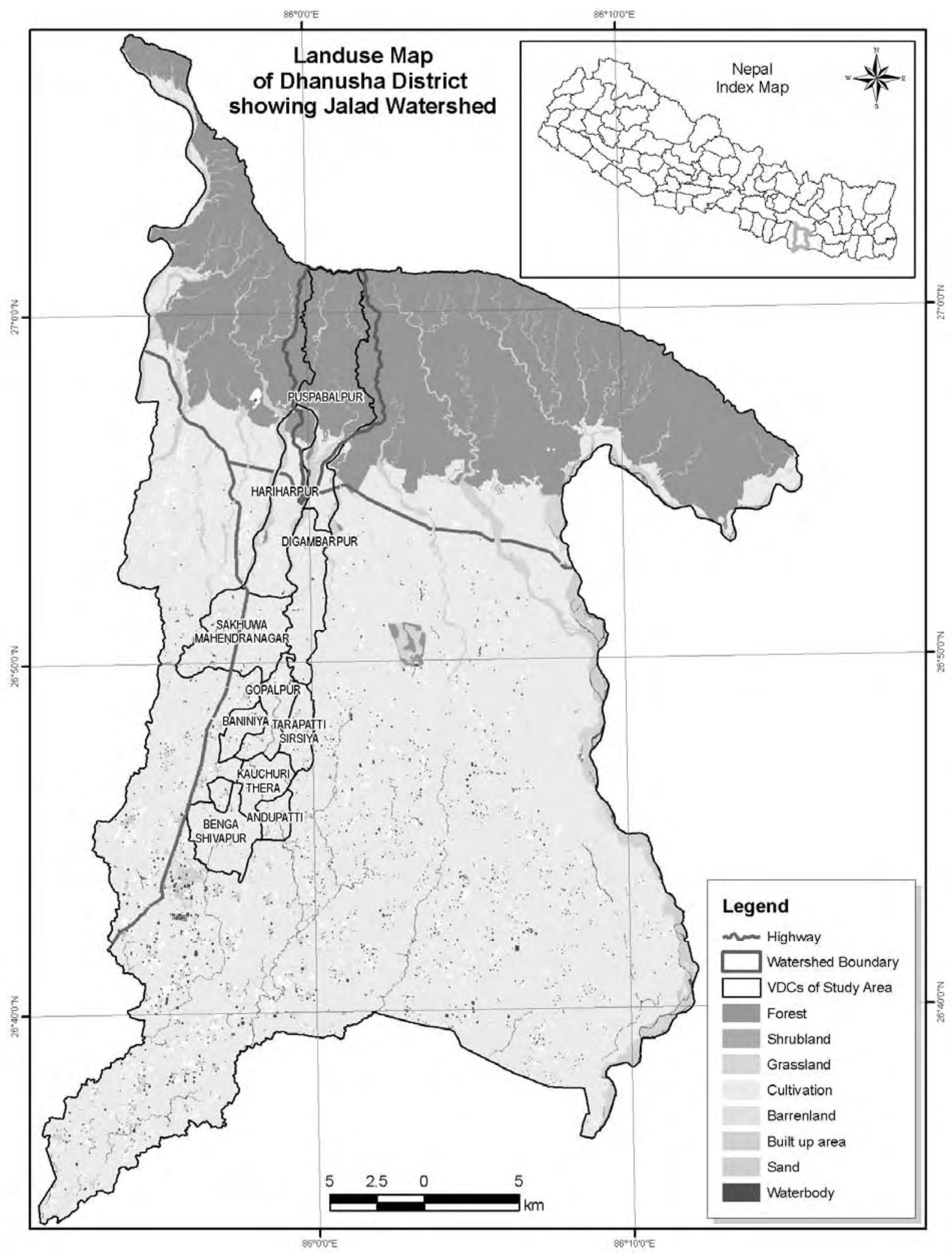

Source: Department of Survey/GON, Topographic Map, 1996

Fig 1 : Study Area in Dhanusha district, Nepal 
Forest inventory was done to assess the density of the forest (seedlings, saplings, poles, and trees per hectare) in the Jalad sub-watershed area, according to the Guideline for Inventory of Community Forests, 2004.

Geographical Information System (GIS) and Global Positioning System (GPS) were used to measure the width of the river and inventory the forest. Further, GIS enabled the comparison of river width with past records and to measure how much productive agricultural land area had been converted into unproductive river beds due to river-cutting in upstream and deposition of silts in downstream.

\section{Results and discussion}

Forest stocking in the upstream watershed area of the Jalad River in the Churia hills were: 19 trees, 351 poles, 2539 saplings and 4346 seedlings per hectare (Table 1). The forest condition was poor due to overextraction of trees and poles for fuel wood and timber. The seedlings and saplings were negatively affected by frequent forest fires and heavy grazing. According to the Community Forest Inventory Guidelines (2004), 2000-5000 seedlings per hectare is categorized as 'fairly good' more than 2000 saplings per hectare is categorized as 'good' (CPFD, 2004). However, the number of trees and poles per hectare were found to be considerably low.

Table 1 : Forest condition in the Churia hills of Jalad watershed area of the Jalad River

\begin{tabular}{clr}
\hline SN & \multicolumn{1}{c}{ Category } & No. / ha \\
\hline 1 & Trees (more than 30 cm diameter) & 19 \\
2 & Poles (10-30 cm diameter) & 351 \\
3 & Saplings (more than 1 meter tall with & 2539 \\
& diameter below 10 cm) & \\
4 & Seedling or regeneration (less than 1 & 4346 \\
& meter seedling of tree species) & \\
\hline
\end{tabular}

Source: Forest Inventory by SIRF, 2008

Both observation and forest inventory confirmed that the Churia hill forest resources were rapidly deteriorating both in quality and quantity due to heavy grazing, over-exploitation of forest products for firewood and timber and by frequent fires. The people of Madhubasa village were gradually encroaching on the forest. The heavy pressures on the forest resources and over-extraction of the forest products had significantly degraded the watershed area of the Jalad River.

Initially, it was assumed that the local community people grazed their animals only in the areas they could commute within a day. But the study revealed three grazing patterns in the watershed areas. They were:

(i) The local community people grazed their animals to the extent that they could return home in a day. Such grazing was practiced throughout the year within $6 \mathrm{~km}$ of the outer face of the Churia hills.

(ii) During the rainy reason, grazing was prohibited in some Terai villages after rice planting in JulyAugust. Some of the households in the midstream constructed temporary animal-sheds in the Churia foothills outside the forest and grazing was done to the extent they could commute in a day. This type of grazing was carried out mainly during the 4 months of the rainy season.

(iii) The third type of grazing was done in the interior area of the sub-watersheds for 8 months other than the rainy season. The people of the Dhanusha district and Sindhuli districts kept their animal sheds inside the forest. This has greatly damaged the interior watershed. There were at least 8-10 such animal sheds in the watershed area of the Jalad River.

Heavy grazing in the watershed has negative impact on forest resources of the watershed area by contributing directly and indirectly to soil erosion and landslides. In total, about 1400 animals (goats, cows and buffaloes) grazed in the Jalad sub-watersheds daily, contributing to the degradation of the watershed.

Three villages viz. (i) Magar tole of Pushpalpur VDC, (ii) Chheri Pokhar village of Digamberpur Ward No. 4 and (iii) the Kathrait village down to Jalad Bridge, on the Dhanushadham-Janakpur had been completely displaced by river-bank cutting. According to the local people, about 150 households had been affected due to river-bank cutting. Three wells and a bridge can be observed on the middle of the Jalad River as evidence of the effects of river-bank cutting in the villages.

Of the 627 households interviewed, 107 households (17\%) had completely lost their lands. A total of 440 hectares of private lands, 138 hectares of public land and 101 hectares of trustee land had been converted to river-beds. This had negative impacts on the economy of poor households, their livelihoods and food security. 
Table 2 summarizes private land loss due to riverbank cutting and siltation. The 627 households sampled had lost 440 hectares of private lands. Of the private lands, average land loss per household was 0.70 hectare. The maximum loss of the land of a household was 7.33 hectares. Land is a prime property for sustaining livelihoods in the Terai. Land ownership is also a source of social status for wealthy families in the Terai. Analysis of data shows that the upstream and the downstream households had lost more private lands (on an average) than the midstream households.

Community level discussions on the loss of common property in each VDC reported that irrigation canals, schools, common land, trustee land, pond, road, wells, bridges, culverts, club houses and hand pumps had also been destroyed.

\section{Environmental services of the Jalad River}

Irrigation in the midstream and downstream is a clear environment service of the Jalad River. About 16 $\mathrm{km}$ south of the Churia foothills, Hardinath Irrigation Canal was constructed in the midstream of the Jalad River. The Hardinath Irrigation Canal was inaugurated on 24 September 1967. Designed for 2000 hectares of gross command area, only 1694 hectare area has actually been serviced. 21 committees in the Western Branch, 13 committees in the Eastern Branch and one Main committee together regulate this irrigation system. The discharge capacity was 1 cubic meter (1000 liter) per second and it covered 12 VDCs with 3000 households or a population of about 18,000. The total length was $14.5 \mathrm{~km}$. Currently, the deposition of silts and sands by the flood waters in this canal has become very high compared to the past (EVREC, 1998).
The proportion of the total land holding with perennial irrigation facility was $19.5 \%$ while $31 \%$ of the land was partially irrigated, the rest was rain fed. Commonly grown crops in the irrigated area were early and monsoon paddy, wheat, potato, oilseeds and pulses. Almost 100\% of the irrigated land during the monsoon season was reserved for paddy. Wheat was the second crop for the irrigated area, followed by pulses, potato and oilseeds. Table 3 presents the production of major crops in the fully irrigated, partially irrigated and rain fed areas. For example, rice production was 2.8 tons per hectare per year in the irrigated land but only 2.0 tons per hectare per year in the partially irrigated land and 1.4 tons per hectare per year in the rain fed lands.

Availability of water for irrigation from the rivers in the Terai is an environmental service. Though the source of water was from the Churia hills, this has not been acknowledged as an environmental service of the Churia hills by neither the government agencies or by the local communities. Similarly, annual flooding, sedimentation or siltation, and/or riverbank cutting in the Bhabar and/or the Terai have not yet been causally linked as a negative environmental impact due to over-exploitation of natural resources and degradation of watershed in the Churia hills.

The local people reported that the river carried large amounts of sediments during the rainy season. In the past, the Jalad River was deep; now, it has become shallow and overflows into the neighboring agriculture fields during floods. The Jalad River has eroded the upstream and downstream banks and large amounts of sediments have been deposited as a delta in front of the headwork. The discharge capacities

Table 2 : Stream-wise loss of private lands by river-cutting and siltation

\begin{tabular}{lcccc}
\hline $\begin{array}{c}\text { Stream-wise group of } \\
\text { VDCs }\end{array}$ & $\begin{array}{c}\text { Total land loss in } \\
\text { ha (approx) }\end{array}$ & $\begin{array}{c}\text { Total households } \\
\text { HH }\end{array}$ & $\begin{array}{c}\text { Mean land loss in } \\
\text { ha/HH }\end{array}$ & $\begin{array}{c}\text { Max land loss } \\
\text { in ha/HH }\end{array}$ \\
\hline Upstream VDCs & 100 & 116 & 0.86 & 7.33 \\
Midstream VDCs & 105 & 212 & 0.49 & 2.67 \\
Downstream VDCs & 236 & 299 & 0.79 & 5.33 \\
\hline Total & 441 & 627 & 0.71 & \\
\hline Source: Social Survey, Social Inclusion Research Fund (SIRF), 2008 &
\end{tabular}

Table 3 : Difference in agriculture production in the command area of Hardinath Irrigation System

\begin{tabular}{lccccc}
\hline \multirow{2}{*}{ Types of land } & \multicolumn{4}{c}{ Average production in metric ton/ha } \\
\cline { 2 - 6 } & Paddy & Wheat & Potato & Pulse & Oil seed \\
\hline Irrigation facility for the whole year & 2.8 & 1.75 & 12.0 & 0.97 & 0.87 \\
Partial irrigation facility & 2.0 & 1.25 & 8.7 & 0.80 & 0.75 \\
Rain fed land & 1.4 & 0.00 & 0.0 & 0.67 & 0.53 \\
\hline
\end{tabular}

Source: Everest Research Center (EVREC), 1998 
of the main canals have been diminished due to the deposition of sediments. This has negatively affected the irrigation of the agriculture land leading to low production of crops and ultimately to food insecurity. Currently, irrigation areas have been reduced from 1600 hectares to about 1200 hectares during monsoon and to 300 hectares during the nonmonsoon period (EVREC, 1998).

When queried why the Jalad River had negatively affected more land now than 5-6 decades ago, the local people offered some cogent explanations. In the past, three streams of Jalad Rivers namely: Chamainiya, Jagadhar and Jalad itself used to flow separately. Chamainiya stream used to meet about 2 $\mathrm{km}$ south from the point where they currently meet. Similarly, Jagadhar stream used to meet about $15 \mathrm{~km}$ south in Jalad stream just before the Hardinath irrigation dam but at present it meets at the Churia foothills. The meeting of Jagadhar and Chamainiya streams at the Churia foothills augmented the flood water volume and caused serious negative impacts such as river bank cutting and over flooding.

In the past, the downstream people had collected the forest products from the Jalad watershed for their basic needs only. Now they harvest forest products both for the fulfillment of their basic needs and for commercial purposes and did not hesitate to fell trees, poles and saplings. The gorges of the Churia hills were choked with bamboo clumps and the forest canopy and ground cover was so thick in the past that they not only slowed the speed and energy of the flood but also absorbed huge amounts of water into the Churia hills. Thus, only a small amount of water flowed out into the streams and this caused less floods and river-cutting effects in the Bhabar and the Terai. Moreover, the river beds of the Jalad and Jagadhar streams were covered with dense forests of Sissoo (Dalbergia sissoo) and Khair (Acacia catechu) that served as filters. Presently, there are no such forests in the upstream to serve this purpose.

The Bhabar with only sub-surface water plays an important role for the Terai. River water cannot be detected in the Bhabar zone. Nine kilometers of Jalad River flows through the dense foothills. According to the local people, 6-7 decades ago, the Bhabar zone was covered with dense forest that soaked the percolating water at sub-surface level and released only small amount of overland flow so there was only nominal negative effect in the Terai zone. Currently, there is only a small patch of community forest in the western bank of the Bhabar zone along the Jalad River.

A small amount of rain water directly flows into the creeks and streams loaded with heavy quantities of sand, gravel and stone, and turns into a big flood when it comes to the river. Even in a small rain, it causes a lot of damage in the Bhabar and the Terai zone. Thus, there is a direct linkage between upstream and downstream.

According to the Freeman's Stakeholder Theory (2001), the stakeholders are "groups and individuals who benefit from or are harmed by, and whose rights are violated or respected by corporate actions". Any group or individual who can affect, or is affected by, are considered stakeholders. Although downstream communities were victims of the Jalad River, they have not been recognized as stakeholders and so they have been excluded in the conservation and management of the upstream Churia hills resources. There was a lack of awareness among the river-affected downstream people, communities and government and/or nongovernment organizations and community-based organizations that they were also key stakeholders of the Jalad River.

The major problems/issues related with the environmental services were: (a) lack of explicit government policy on environmental services, (b) lack of accounting system developed and approved by the government agencies for environmental services, (c) lack of awareness among the public and most of the stakeholders on environmental services, (d) environmental services were neither recognized nor institutionalized in the concerned agencies, and (e) lack of research evidence to convince the policy makers to recognize and institutionalize the environmental services.

Some of the challenges concerning PES set up in Nepal are:

- Lack of scientific evidences establishing linkages between watershed ecosystem management and hydrological services generated despite its efforts on watershed management;

- Lack of awareness regarding PES concept among people, resource managers and policy makers and lack of recognition in national policies; and

- Lack of property rights in the hills which complicates the design and implementation of PES schemes. 
The Ministry of Forests and Soil Conservation ought to develop a comprehensive policy and laws to launch programs for upstream-downstream linkage between the Churia and the Terai, in close consultation with the local government and other concerned agencies. Recognizing Churia as a fragile ecological zone, the Chure-Bhabar and the Terai should be considered as one management regime within one administrative and political unit. Ecologically, the Churia and the Terai should be considered as one landscape for protecting Terai. Changing the behavior of the people living nearby must be a priority to reduce the extraction of tangible products. Over-exploitation of Churia resources should be reduced to protect Terai, the granary of the country. Given that food products are now imported, the Terai food production cannot be sustained without the conservation of Churia. It is a must for national food security. Investment on the Chure conservation must be done for its environmental services to Terai agriculture.

\section{Conclusion}

Ecologically, Churia, Bhabar and Terai zones are interlinked. They should not be separated for management purposes in the restructuring of state boundary based on settlement of Hill or Terai originpeople. The downstream communities are the key stakeholders for the conservation and management of the Churia hills. Their roles and responsibilities should be recognized and well defined.

This study has determined that upstream land use change including deforestation, forest degradation, agriculture, ranching and/or over-grazing were major problems responsible for watershed degradation leading to major environmental problems in terms of siltation downstream. Siltation in the Terai should be viewed as a breakdown of environmental services by watersheds of the Churia hills. This has not yet been recognized by the government agencies or by the local communities due to a lack of awareness, knowledge, skills and also due to acute poverty in the upstream Churia hills and the downstream Terai agricultural communities. Similarly, annual flooding, sedimentation or siltation, and/or river-bank cutting in the Bhabar and/or the Terai have not yet been considered as negative environmental products nor has its harmful impact due to over-exploitation of natural resources and degradation of watershed or sub-watersheds in the Churia hills been acknowledged. In a nutshell, Churia hills and the Terai should be interlinked along the perspective of environmental services.

\section{Acknowledgements}

The author would like to express his sincere gratitude to Prof. Dr. Abhoy Kumar Das and Dr. Binod Bhatta for their guidance and to Dr. S. N. Rai and Mr. Sahas Man Shrestha for their inputs. The Social Inclusion Research Fund (SIRF) of the Winrock International, Kathmandu and the Indigenous Peoples Foundation, Kathmandu provided funding for this study.

\section{References}

CPFD. 2004. Revised Guideline for Inventory of Community Forests. Community and Private Forest Division, Department of Forest, Kathmandu, Nepal (Nepali version). 47p.

EVREC. 1998. Diagnostic Study of Hardinath Irrigation System (Final Report). Everest Research Center, Kathmandu, Nepal, 39-41.

Freeman, R.E. 2001. A Stakeholder Theory of Modern Corporation. In Business Ethics ( $3^{\text {rd }}$ ed.) (eds) Snoeyenbos, Almender and Humber, Newyork, Prometheus Books, 101-114.

Hardin, G. 1968. The Tragedy of Commons. Science 162: $1243-1248$.

\section{LRMP. 1986. Land Resource Mapping Project} Report, Kathmandu, Nepal.

Muñoz G., Guevara, A., Torres J.M., and Braña, J. 2008. Paying for the Hydrological Services of Mexico's Forests: Analysis, Negotiations and Results. Ecological Economics 65: 725-736. www.elsevier.com or www.sciencedirect.com

Pagiola, S. 2008. Payments for Environmental Services in Costa Rica. Ecological Economics 65: 712724. www.sciencedirect.com

Wunder, S. 2005. Payments for Environmental Services: Some Nuts and Bolts. CIFOR Occasional Paper No. 42, Bogor, Indonesia, 2-3.

Wunder, S. and Albán, M. 2008. Decentralized Payments for Environmental Services: The Case of Pimampiro, Ecuador. Ecological Economics 67: 685-698. www.sciencedirect.com. 